\title{
NMR and X-ray characterization of steroids with furospirostane side chains
}

\author{
Mariana Macías-Alonso, Nuria Esturau-Escofet, Marcos Flores-Álamo, \\ Rafael Moreno-Esparza,* and Martín A. Iglesias-Arteaga* \\ Facultad de Química, Universidad Nacional Autónoma de México, \\ Ciudad Universitaria, 04510 México,D.F., México \\ E-mail: moresp@servidor.unam.mx, martin.iglesias@servidor.unam.mx
}

\begin{abstract}
The synthesis and assignment of ${ }^{1} \mathrm{H}$ and ${ }^{13} \mathrm{C}$ NMR signals and X-Ray characterization of steroids bearing furospirostane side chains is provided. The effects of the side chain modifications on the puckering parameters and NMR characteristics derived from the modification of the side chains are discussed.
\end{abstract}

Keywords: Steroids, furospirostanes, NMR, X-Ray structures, puckering

\section{Introduction}

Steroids bearing oxygenated spiroketal side chains are widespread in both the natural and synthetic domains. Steroid sapogenins, which have produced a large variety of interesting reactions and rearrangements, ${ }^{1}$ are characterized by the presence of a 16ß,22:22,26-diepoxy moiety in side chain and can be regarded as 1,6-dioxaspiro[4.5]decane derivatives (Figure 1). This kind of compound has been subject of much research due to their biological activity ${ }^{2}$ and their usefulness as starting materials for the synthesis of different bioactive compounds as sexual or adrenocortical hormones, ${ }^{1 \mathrm{a}}$ ecdysteroids, ${ }^{3}$ plant growth stimulators, ${ }^{4}$ and cytotoxic steroids ${ }^{5}$ among others. 


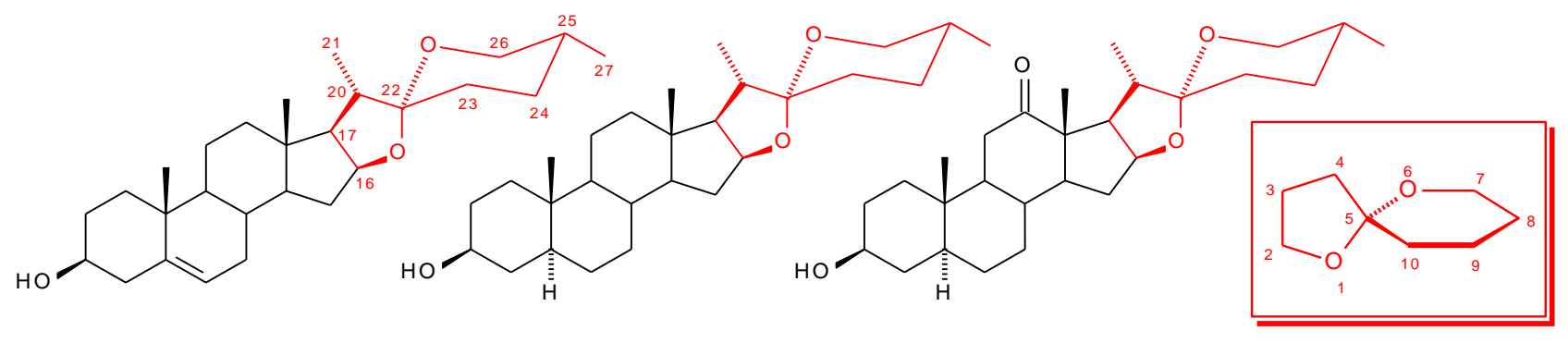

1 diosgenin

2 tigogenin

3 hecogenin

1,6-dioxaspiro[4.5]decane

Figure 1. Some naturally occurring steroid sapogenins.

Furospirostanes, a smaller and relatively less known family of steroids bearing a 16ß,22:22,25-diepoxy moiety in the chain, may be considered 1,6-dioxaspiro[4.4]nonane derivatives, and include compounds with antitumor activity as the ritterazines $4,{ }^{5 \mathrm{f}}$ cephalostatines $\mathbf{5},{ }^{5 f}$ or hippuristanols $\mathbf{6 - 8},{ }^{6}$ among others (see Figure 2).

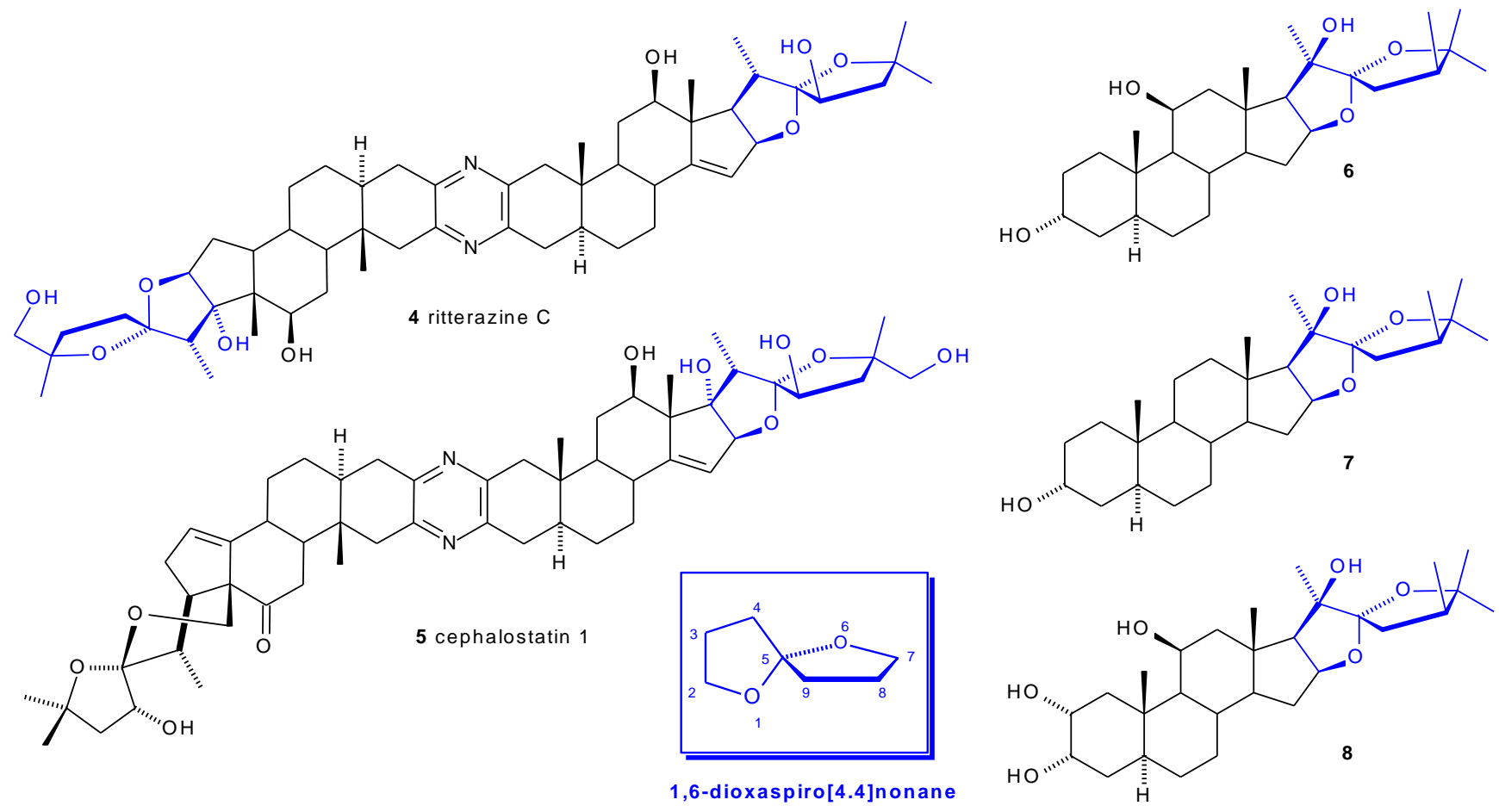

Figure 2. Some furospirostanes with cytotoxic activity against cancer cells.

As a part of our project to explore the reactivity of steroid bearing spiroketals side chains, we have recently focused our attention on the 16 $\beta, 22: 22,25$-diepoxy moiety derived from our recently reported hypervalent iodine-induced F-ring contraction (see Scheme 1). ${ }^{\text {if }}$ 


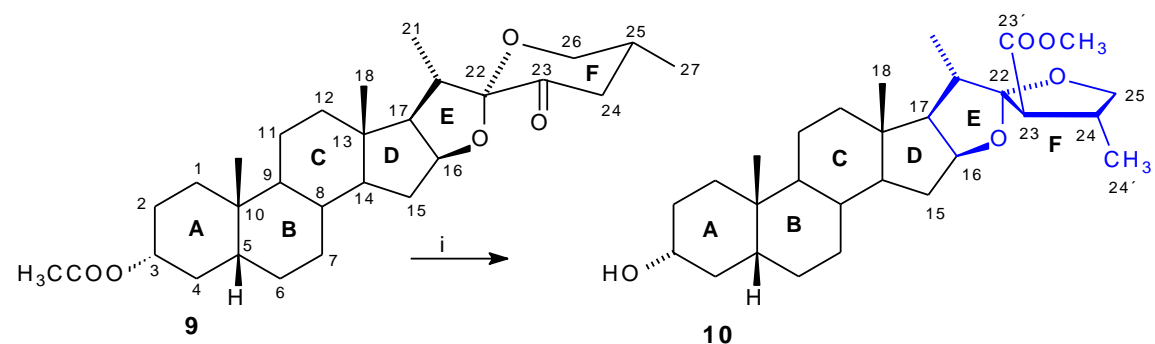

i) $\mathrm{KOH} / \mathrm{MeOH} / \mathrm{DIB}$, R.T, $1.5 \mathrm{hr}$

\section{Scheme 1}

In this context and for structural reference purposes, we decided to carry out a detailed characterization of compounds bearing such functionality that serve as materials for our biological, synthetic and chemical reactivity studies. In this communication we describe the unambiguous assignment of all ${ }^{1} \mathrm{H}$ and ${ }^{13} \mathrm{C}$ chemical shifts of spirocyclic steroids bearing the $16 \beta, 22: 22,25$-diepoxy moiety in the side chain. In addition a detailed analysis of the crystal structures of such compounds is also provided.

\section{Results and Discussion}

Since compound $\mathbf{1 0}$ persisted in crystallizing in needles not suitable or X-Ray studies, derivatization of $\mathbf{1 0}$ was necessary. Hence the acetate 11 was prepared in $74.8 \%$ yield by the standard $\mathrm{Ac}_{2} \mathrm{O}$ /pyridine procedure. $\mathrm{LiAlH}_{4}$ reduction of $\mathbf{1 0}$ afforded the diol $\mathbf{1 2}$ in 84.9 yield (see Scheme 2).

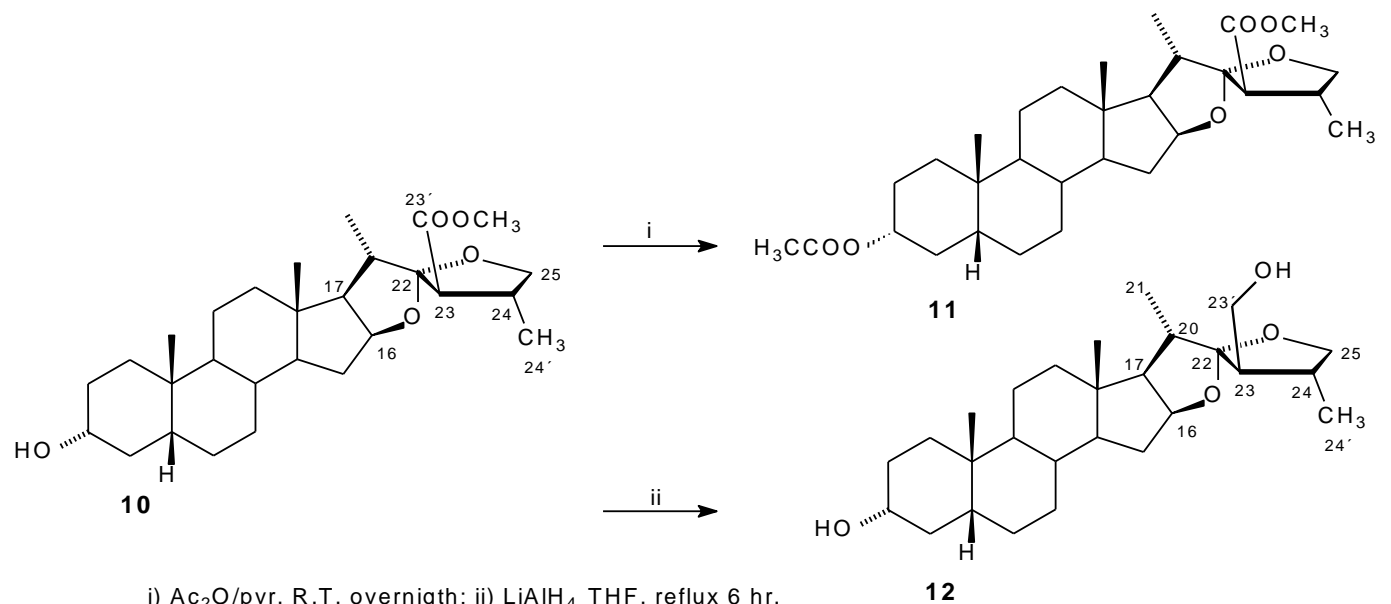

\section{Scheme 2}




\section{${ }^{1} \mathrm{H}$ NMR Characteristic derived from the steroid nucleus.}

Several papers have dealt with the total assignment of protons attached to the steroid framework. In particular Kirk ${ }^{7 \mathrm{a}}$ and Agrawal $^{7 \mathrm{~b}}$ have provided excellent reference papers that also provided useful hints for the assignment of the ${ }^{1} \mathrm{H}$ signals of naturally occurring and synthetic steroids. Although we are providing the total assignment of the ${ }^{1} \mathrm{H}$ signals of all the studied compounds, the discussion will be focused in the ${ }^{1} \mathrm{H}$ signals associated to the $16 \beta$, 22:22,25-diepoxy side chain.

\section{${ }^{1}$ H NMR Characteristic derived from the 16 $\beta, 22: 22,25$-diepoxy side chain.}

The contraction of the F-ring produces significant changes on the signals of the protons placed in the side chain. In particular the furospirostane side chains of compounds $\mathbf{1 0}$ and $\mathbf{1 1}$ are characterized by the presence of a new deshielded signal corresponding to $\mathrm{H}-23$ in $\alpha$ position of both the spiroketal function at $\mathrm{C}-22$ and the carboxymethyl group attached to $\mathrm{C}-23$. The conversion of the F-ring into a 5-membered cycle also produces strong deshielding of H-25 Pro$S$ (formerly H-26 Pro-S in compound 9) and shielding of H-25 Pro-R, (formerly H-26 Pro- $R$ in 9).

Similarly, upfield shift of H-20 and downfield shifts of both H-24 (formerly H-25 in 9) and H-24' (formerly H-27 in 9) are also associated to the F-ring contraction that gave place to compound 10. Table 1 shows the key 2D homo- and heteronuclear correlations that allow the unambiguous assignment of most of the ${ }^{1} \mathrm{H}$ signals associated to the (23R)-23-carboxymethyl$16 \beta, 22: 22,25$-diepoxy side chain of compound 10, (see Figure 3 for key H-H correlations and supplementary information file for annotated spectra).

Table 1. Main hetero- and homonuclear correlations of the side chain of compound $\mathbf{1 0}$

\begin{tabular}{ccccc}
\hline H & COSY & NOESY & \multicolumn{2}{c}{ HMBC H-C } \\
& $\mathrm{H}-\mathrm{H}$ & $\mathrm{H}-\mathrm{H}$ & 2 bonds & 3 bonds \\
\hline $20 \beta$ & $17 \alpha, 21$ & $12 \beta, 18,21, \mathrm{CH}_{3} \mathrm{O}$ & $17,21,22$ & 13,23 \\
21 & $20 \beta$ & $20 \beta, 24, \mathrm{CH}_{3} \mathrm{O}$ & 20 & 17,22 \\
23 & 24 & $18,24,24^{\prime}$ & $22,23^{\prime}, 24$ & $24^{\prime}$ \\
24 & 23,25 Pro- $R, 25$ Pro-S & $21,23,25$ Pro-S & 23,25 & $23^{\prime}$ \\
$24^{\prime}$ & 24 & $23,24,25$ Pro- $R$ & 24 & 23,25 \\
25 Pro- $R$ & 24 & $24^{\prime}$ & 24 & $23,24^{\prime}$ \\
25 Pro- $S$ & 24 & 24 & 24 & 22,23 \\
\hline
\end{tabular}



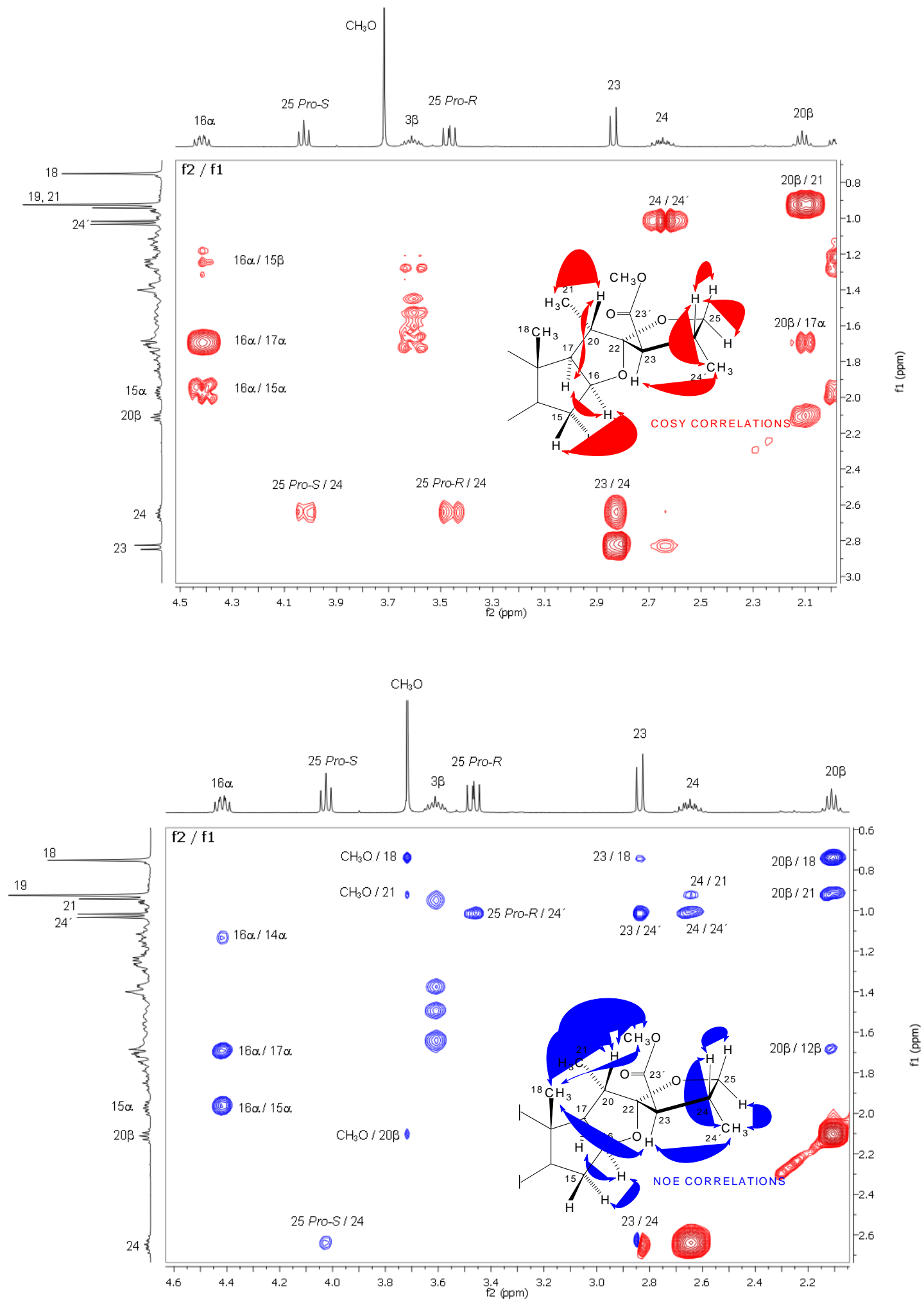

Figure 3. Selected H-H and NOE correlations in the side chain of compound $\mathbf{1 0 .}$ 
The reduction of the carboxymethyl group in $\mathbf{1 0}$ to produce the diol $\mathbf{1 2}$ results in the downfield shift of $\mathrm{H}-20$ and the upfield shift of $\mathrm{H}-23$. The ${ }^{1} \mathrm{H}$ spectrum of the reduced compound 12 also shows two new signals corresponding to the diasterotopic hydrogens attached to C-23' which shows the typical AB-X coupling pattern. Table 2 shows the key $2 \mathrm{D}$ homo- and heteronuclear correlations that allow the unambiguous assignment of most of the ${ }^{1} \mathrm{H}$ signals associated to the (23S)-23-hydroxymethylene-16 $\beta, 22: 22,25$-diepoxy side chain of compound 12, (see Figure 4 for key H-H correlations and supplementary information file for annotated spectra).

Table 2. Main hetero- and homonuclear correlations of the side chain of compound $\mathbf{1 2}$

\begin{tabular}{ccccc}
\hline H & COSY & NOESY & \multicolumn{2}{c}{ HMBC H-C } \\
& H-H & H-H & 2 bonds & 3 bonds \\
\hline $20 \beta$ & $17 \alpha, 21$ & $12 \beta, 18,21$ & $17,21,22$ & 13,23, \\
21 & $20 \beta$ & $20 \beta, 23^{\prime} \mathrm{a}, 23 \mathrm{~b}$ & 20 & 17,22 \\
$2 *^{* *} 24$ & $23^{\prime} \mathrm{a}, 2^{\prime} 3^{\prime} \mathrm{b}$ & $23^{\prime} \mathrm{a}, 23^{\prime} \mathrm{b}, 24^{\prime}$ & 24 & - \\
$23^{\prime} \mathrm{a}$ & 23 & $21,23,20 \beta$ & 23 & 22 \\
$23^{\prime} \mathrm{b}$ & 23 & $21,23,20 \beta$ & 23 & 22,24 \\
$2 *^{*} 23$ & 25 Pro- $R, 25$ Pro-S & 25 Pro-S & 23,25 & - \\
$24^{\prime}$ & 24 & 23,25 Pro- $R$ & 24 & 23,25 \\
25 Pro $-R$ & 24 & $24^{\prime}$ & 24 & $24^{\prime}$ \\
25 Pro $-S$ & 24 & 24 & 24 & 22,23 \\
\hline
\end{tabular}

**overlapped

While the comparison between the coupling constants of the protons in the side chain of the spirostane derivative $\mathbf{9}$ with those of the furospirostanes $\mathbf{1 0}$ to $\mathbf{1 2}$ indicates that the conversion of 6-membered F-ring into a 5-membered ring results in the expected and evident conformational changes, the coincidence of the coupling constants of H-23 pro- $R$ in compounds 11 and 12 suggests that the conversion of the carboxymethyl moiety of $\mathbf{1 1}$ into the exocyclic hydroxymethylene of $\mathbf{1 2}$ does not induce significant conformational changes in the side chain.

${ }^{13} \mathrm{C}$ NMR discussion. In addition to the extensive collection of the ${ }^{13} \mathrm{C}$ chemical shifts of around 400 steroids built up by Blunt and Stothers, ${ }^{8 a}$ Agrawal published an excellent review which comprises the assignment of the ${ }^{13} \mathrm{C}$ chemicals shifts of 66 steroid sapogenins bearing the $16 \beta, 22: 22,26$-diepoxy in the side chain. ${ }^{8 b}$ Some of our previous works on this subject have also provided rules for the systematization of the effects exerted by different functional groups in NMR signals of the 16ß,22:22,26-diepoxy side chain. ${ }^{8 c-e}$ Consequently, the discussion here will be will be focused in the main NMR characteristic associated with the 5-membered 16 $\beta, 22: 22,25$-diepoxy side chain result of the F-ring contraction (see crystallographic studies). 

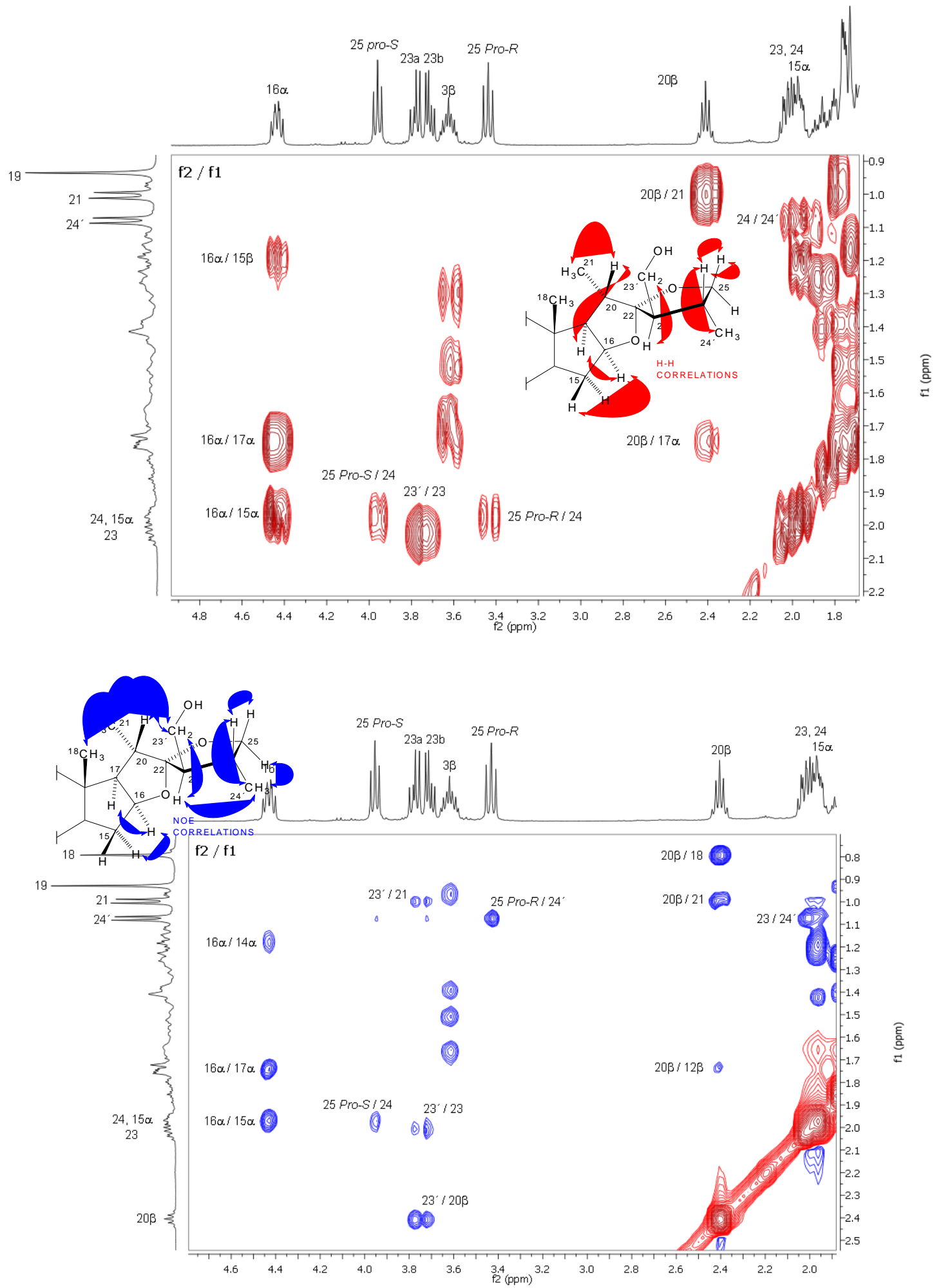

Figure 4. Selected H-H and NOE correlations in the side chain of compound $\mathbf{1 2 .}$ 
Table 3. ${ }^{1} \mathrm{H}$ chemical shifts of the compounds $\mathbf{9}$ to $\mathbf{1 2}$

\begin{tabular}{|c|c|c|c|c|c|}
\hline $\mathrm{H}$ & 9* & $\mathrm{H}$ & 10 & 11 & 12 \\
\hline $1 \alpha$ & 1.80 & $1 \alpha$ & 1.79 & 1.78 & 1.78 \\
\hline $1 \beta$ & 1.02 & $1 \beta$ & 0.96 & 1.01 & 0.97 \\
\hline $2 \alpha$ & 1.38 & $2 \alpha$ & 1.29 & 1.37 & 1.30 \\
\hline $2 \beta$ & 1.67 & $2 \beta$ & 1.66 & 1.66 & 1.66 \\
\hline $3 \beta$ & $4.71(\mathrm{~m})$ & $3 \beta$ & $3.62(\mathrm{~m})$ & $4.69(\mathrm{~m})$ & $\begin{array}{c}3.62(\mathrm{ddd}, J=15.7 \\
10.9,4.7)\end{array}$ \\
\hline $4 \alpha$ & 1.80 & $4 \alpha$ & 1.73 & 1.79 & 1.74 \\
\hline $4 \beta$ & 1.53 & $4 \beta$ & 1.51 & 1.52 & 1.51 \\
\hline $5 \beta$ & 1.44 & $5 \beta$ & 1.40 & 1.43 & 1.39 \\
\hline $6 \alpha$ & 1.23 & $6 \alpha$ & 1.25 & 1.23 & 1.53 \\
\hline $6 \beta$ & 1.85 & $6 \beta$ & 1.85 & 1.84 & 1.84 \\
\hline $7 \alpha$ & 1.07 & $7 \alpha$ & 1.09 & 1.07 & 1.10 \\
\hline $7 \beta$ & 1.38 & $7 \beta$ & 1.43 & 1.37 & 1.40 \\
\hline $8 \beta$ & 1.57 & $8 \beta$ & 1.57 & 1.57 & 1.57 \\
\hline $9 \alpha$ & 1.40 & $9 \alpha$ & 1.40 & 1.39 & 1.41 \\
\hline $11 \alpha$ & 1.38 & $11 \alpha$ & 1.39 & 1.70 & 1.40 \\
\hline $11 \beta$ & 1.23 & $11 \beta$ & 1.21 & 1.21 & 1.24 \\
\hline $12 \alpha$ & 1.13 & $12 \alpha$ & 1.12 & 1.12 & 1.17 \\
\hline $12 \beta$ & 1.74 & $12 \beta$ & 1.71 & 1.69 & 1.73 \\
\hline $14 \alpha$ & 1.15 & $14 \alpha$ & 1.13 & 1.14 & 1.17 \\
\hline $15 \alpha$ & 1.98 & $15 \alpha$ & 1.98 & 1.95 & 1.99 \\
\hline $15 \beta$ & 1.27 & $15 \beta$ & 1.26 & 1.23 & 1.22 \\
\hline $16 \alpha$ & $\begin{array}{c}4.59(\mathrm{td}, J= \\
7.6,6.2)\end{array}$ & $16 \alpha$ & $\begin{array}{c}4.42(\mathrm{td}, J= \\
\quad 7.7,6.0)\end{array}$ & $\begin{array}{c}4.40(\mathrm{td}, J= \\
7.7,6.0)\end{array}$ & $4.43(\mathrm{~m})$ \\
\hline $17 \alpha$ & 1.74 & $17 \alpha$ & 1.71 & 1.69 & 1.74 \\
\hline $\begin{array}{c}18 \\
\left(\mathrm{CH}_{3}\right)\end{array}$ & $0.74(\mathrm{~s})$ & $\begin{array}{c}18 \\
\left(\mathrm{CH}_{3}\right)\end{array}$ & $0.75(\mathrm{~s})$ & $0.74(\mathrm{~s})$ & $0.79(\mathrm{~s})$ \\
\hline $\begin{array}{c}19 \\
\left(\mathrm{CH}_{3}\right)\end{array}$ & $0.93(\mathrm{~s})$ & $\begin{array}{c}19 \\
\left(\mathrm{CH}_{3}\right)\end{array}$ & $0.92(\mathrm{~s})$ & $0.92(\mathrm{~s})$ & $0.93(\mathrm{~s})$ \\
\hline $20 \beta$ & $\begin{array}{c}2.86 \text { (quin, } J= \\
6.9 \text { ) }\end{array}$ & $20 \beta$ & $\begin{array}{c}2.11 \text { (quin, } J= \\
6.8 \text { ) }\end{array}$ & $\begin{array}{c}2.10 \text { (quin, } J= \\
6.8 \text { ) }\end{array}$ & 2.41 (quin, $J=6.8$ ) \\
\hline $\begin{array}{c}21 \\
\left(\mathrm{CH}_{3}\right)\end{array}$ & $0.92(\mathrm{~d}, J=7.0)$ & $\begin{array}{c}21 \\
\left(\mathrm{CH}_{3}\right)\end{array}$ & $0.93(\mathrm{~d}, J=7.4)$ & $0.92(\mathrm{~d}, J=6.9)$ & $1.00(\mathrm{~d}, J=6.9)$ \\
\hline 23 & - & 23 & $2.84(\mathrm{~d}, J=9.4)$ & $2.82(\mathrm{~d}, J=9.3)$ & $1.99(\mathrm{~m})$ \\
\hline $23^{\prime} \mathrm{a}$ & - & $23^{\prime} \mathrm{a}$ & & & $\begin{array}{c}3.78(\mathrm{dd}, J=10.9 \\
7.1)\end{array}$ \\
\hline $23^{\prime} \mathrm{b}$ & - & $23^{\prime} \mathrm{b}$ & 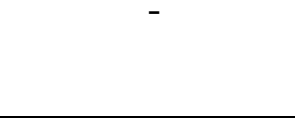 & - & $\begin{array}{c}3.71(\mathrm{dd}, J=10.9 \\
5.5)\end{array}$ \\
\hline
\end{tabular}


Table 3. Continued

\begin{tabular}{|c|c|c|c|c|c|}
\hline $\mathrm{H}$ & $\mathbf{9}$ & $H$ & $\mathbf{1 0}$ & $\mathbf{1 1}$ & $\mathbf{1 2}$ \\
\hline $\begin{array}{c}24 \text { Pro- } S \\
\text { (ax.) }\end{array}$ & $2.42(\mathrm{~m})$ & - & - & - & - \\
\hline $\begin{array}{c}24 \text { Pro- } R \\
\text { (eq.) }\end{array}$ & $\begin{array}{c}2.47(\mathrm{dd}, J= \\
10.7,10.7)\end{array}$ & - & - & - & - \\
\hline 25 & $2.27(\mathrm{~m})$ & 24 & $2.65(\mathrm{~m})$ & $2.64(\mathrm{~m})$ & $1.99(\mathrm{~m})$ \\
\hline $\begin{array}{c}26 \text { Pro- } S \\
\text { (eq.) }\end{array}$ & $\begin{array}{c}3.57(\mathrm{ddd}, J= \\
11.2,4.6,1.4)\end{array}$ & 25 pro- $S$ & $\begin{array}{c}4.03(\mathrm{dd}, J= \\
7.7,7.7)\end{array}$ & $\begin{array}{c}4.01(\mathrm{dd}, J= \\
7.7,7.7)\end{array}$ & $\begin{array}{c}3.95(\mathrm{~d}, J= \\
7.6,7.6)\end{array}$ \\
\hline $\begin{array}{c}26 \text { Pro- } R \\
\text { (ax.) }\end{array}$ & $3.77(\mathrm{dd}, J=$ & 25 pro- $R$ & $\begin{array}{c}3.47(\mathrm{dd}, J \\
=10.1,8.1)\end{array}$ & $\begin{array}{c}3.46(\mathrm{dd}, J= \\
10.1,8.1)\end{array}$ & $\begin{array}{c}3.43(\mathrm{dd}, J= \\
9.3,8.2)\end{array}$ \\
\hline $27\left(\mathrm{CH}_{3}\right)$ & $0.92(\mathrm{~d}, J=6.6)$ & $24^{\prime}\left(\mathrm{CH}_{3}\right)$ & $\begin{array}{c}1.03(\mathrm{~d}, J= \\
6.6)\end{array}$ & $\begin{array}{c}1.01(\mathrm{~d}, J= \\
6.6)\end{array}$ & $\begin{array}{c}1.07(\mathrm{~d}, J= \\
6.3)\end{array}$ \\
\hline & $2.01(\mathrm{~s})$ & $\mathrm{CH}_{3} \mathrm{COO}_{-3}$ & - & $2.00(\mathrm{~s})$ & - \\
\hline & & $\mathrm{CH}_{3} \mathrm{O}$ & $3.72(\mathrm{~s})$ & $3.71(\mathrm{~s})$ & \\
\hline
\end{tabular}

*Signals of compound $\mathbf{9}^{8 \mathrm{e}}$ are included for reference

\section{${ }^{13} \mathrm{C}$ NMR characteristics of the $16 \beta, 22: 22,25$-diepoxy side chain.}

The conversion of the F-ring of $\mathbf{9}$ into the 5-membered ring of $\mathbf{1 0}$ produces the downfield shift of C-25 (formerly C-26 in 9) that now resonates at between 71.8 and $72.5 \mathrm{ppm}$ as a result of the lost of the 1,3 shielding interactions present in the 6-membered F-ring of compound 9. In addition, the 16ß,22:22,25-diepoxy side chains of compounds $\mathbf{1 0}$ to $\mathbf{1 2}$ are characterized by the presence of a deshielded signal corresponding to the spiroketal carbon C-22 between 119 and $120 \mathrm{ppm}$ (See Table 4).

In particular the ${ }^{13} \mathrm{C}$ spectra of compounds $\mathbf{1 0}$ and $\mathbf{1 1}$ are characterized by the presence of the signal corresponding to $\mathrm{C}-23$ around $59.7 \mathrm{ppm}$ and the those corresponding to the exocyclic carboxymethyl group attached to $\mathrm{C}-23$ around $172 \mathrm{ppm}(\mathrm{C}=\mathrm{O})$ and $51.8\left(\mathrm{OCH}_{3}\right)$. The F-ring contraction also produces a slight upfield shift on C-24' (formerly C-27 in compound 9 ) as well as slight downfield shifts on C-20, C-21 and C-24 (formerly C-25 in compound 9 ).

As expected, the reduction of the exocyclic carboxylic ester moiety to produce an exocyclic hydroxy methylene results on the upfield shifts of the signals of C-23 and C-23'. Provided that the reduction of the $\mathrm{C}-23^{\prime}$ carboxyl ester moiety attached to C-23 does not produce significant conformational changes in the side chain (vide supra), the slight upfield and downfield shifts observed in other $\mathrm{C}$ nuclei of the side chain should be attributed to field changes associated to the conversion of the magnetically anisotropic carboxymethyl moiety into a hydroxymethylene group. 


\section{Crystallographic studies}

Table 4. ${ }^{13} \mathrm{C}$ chemical shifts of compounds 9 to 12

\begin{tabular}{|c|c|c|c|c|c|}
\hline $\mathrm{C}$ & 9* & $\mathrm{C}$ & $10^{* * *}$ & $11 * *$ & $12 * *$ \\
\hline 1 & 35.0 & 1 & 35.3 & 35.0 & 35.3 \\
\hline 2 & 26.6 & 2 & 30.5 & 26.5 & 30.5 \\
\hline 3 & 74.2 & 3 & 71.7 & 74.2 & 71.8 \\
\hline 4 & 32.2 & 4 & 36.4 & 32.2 & 36.4 \\
\hline 5 & 41.8 & 5 & 42.0 & 41.8 & 42.0 \\
\hline 6 & 26.9 & 6 & 27.1 & 26.9 & 27.1 \\
\hline 7 & 26.5 & 7 & 26.6 & 26.5 & 26.7 \\
\hline 8 & 35.4 & 8 & 35.5 & 35.5 & 35.5 \\
\hline 9 & 40.5 & 9 & 40.5 & 40.4 & 40.5 \\
\hline 10 & 34.7 & 10 & 34.7 & 34.7 & 34.7 \\
\hline 11 & 20.5 & 11 & 20.5 & 20.5 & 20.6 \\
\hline 12 & 40.0 & 12 & 40.0 & 39.9 & 40.1 \\
\hline 13 & 41.1 & 13 & 41.1 & 41.1 & 41.2 \\
\hline 14 & 56.4 & 14 & 56.2 & 56.2 & 56.2 \\
\hline 15 & 31.7 & 15 & 31.8 & 31.8 & 31.9 \\
\hline 16 & 83.4 & 16 & $81.4(-2.0)$ & $81.4(0)$ & $81.0(-0.4)$ \\
\hline 17 & 61.8 & 17 & $62.7(+0.9)$ & $62.7(0)$ & $62.9(+0.2)$ \\
\hline 18 & 16.1 & 18 & $16.0(-0.1)$ & $16.0(0)$ & $16.4(+0.4)$ \\
\hline 19 & 23.3 & 19 & 23.3 & $23.3(0)$ & $23.4(+0.1)$ \\
\hline 20 & 34.7 & 20 & $37.4(+2.7)$ & $37.4(0)$ & $35.8(-1.6)$ \\
\hline 21 & 14.4 & 21 & $15.5(+1.1)$ & $15.5(0)$ & $16.2(+0.7)$ \\
\hline 22 & 109.8 & 22 & $119.3(+9.5)$ & $119.3(0)$ & $120.2(+0.9)$ \\
\hline 23 & 201.8 & 23 & $59.7(-142.1)$ & $59.6(-0.1)$ & $55.7(-3.9)$ \\
\hline 24 & 45.2 & $23^{\prime}$ & 172.5 & $172.4(-0.1)$ & $62.5(-109.9)$ \\
\hline 25 & 35.8 & 24 & $37.5(+1.7)$ & $37.5(0)$ & $36.9(-0.6)$ \\
\hline 26 & 65.6 & 25 & $72.5(+6.9)$ & $72.5(0)$ & $72.2(-0.3)$ \\
\hline 27 & 17.1 & $24^{\prime}$ & $15.4(-1.7)$ & $15.4(0)$ & $16.3(+0.9)$ \\
\hline CH3COO-3 & 170.5 & CH3COO-3 & - & 170.5 & - \\
\hline \multirow[t]{2}{*}{ CH3COO-3 } & 21.4 & CH3COO-3 & - & 21.4 & - \\
\hline & & CH3O-23' & 51.8 & $51.8(0)$ & - \\
\hline
\end{tabular}

*Signals of compound $\mathbf{9}^{8 \mathrm{e}}$ are included for reference. $* * \Delta \mathrm{ppm}$ associated to the changes in the side chain are given in parentheses and were calculated using the synthetic precursor as reference. 
The absolute configuration of the studied compounds was considered and corroborated as that from the starting steroid sapogenin. ${ }^{8 \mathrm{e}}$ Studied compounds $\mathbf{1 1}$ and $\mathbf{1 2}$ contain the steroid $\mathrm{ABCD}$ fused ring framework with the axial methyl groups attached to $\mathrm{C}-10$ and $\mathrm{C}-13$ cis $\mathrm{A} / \mathrm{B}$, trans $\mathrm{B} / \mathrm{C}$, and trans $\mathrm{C} / \mathrm{D}$ rings junctions, they also bear 16 $\beta, 22: 22,25$-diepoxy moiety characteristic of the furospirostane side chain. Puckering parameters were calculated as described by Cremer and Pople. . $^{\mathrm{a}}$

In compound 11 the equatorial acetoxy group bonded to C-3 is arranged in such a way that the carbonyl $\mathrm{O}$ atom nearly eclipses the axial $\mathrm{H}$ atom attached to $\mathrm{C}-3$ and does not disturb ring A, which present a chair conformation with a puckering amplitude $(\mathrm{Q})=0.555(2) \AA, \theta=$ 178.0(2) ${ }^{\circ}, \varphi=242(5)^{\circ}$, if the calculation starts from $\mathrm{C}-1$ to $\mathrm{C}-10$ and proceeds in a counterclockwise direction. Ring $\mathrm{B}$ assumes a conformation very similar to a chair form with a puckering amplitude Puckering Amplitude (Q) $=0.578(2) \AA, \theta=3.2(2)^{\circ}, \varphi=226(4)^{\circ}{ }^{\circ}$, if the calculation starts from $\mathrm{C}-5$ to $\mathrm{C}-10$ and proceeds in a counterclockwise direction. Ring $\mathrm{C}$ assumes a conformation close to a chair with a puckering amplitude (Q) $=0.569(2) \AA, \theta=9.6(2)$ ${ }^{\circ}, \varphi=254.9(14)^{\circ}$, if the calculation starts from C-8 to $\mathrm{C}-14$ and proceeds in a clockwise direction. Ring D can be described as cyclopentane twisted on C-13-C-14 with puckering parameters of $\mathrm{Q}(2)=0.445(2) \AA, \varphi(2)=202.3(3)^{\circ}$, if the calculation starts from C-13 to C-17 and proceeds in a clockwise direction. Ring E display an envelope $\mathrm{O}(4)$-exo with absolute $\mathrm{L}$ configuration with puckering parameters $\mathrm{Q}(2)=0.350(2) \AA, \varphi(2)=186.2(4){ }^{\circ}$, if the calculation follow this order; $\mathrm{O}(4), \mathrm{C}-22, \mathrm{C}-20, \mathrm{C}-17, \mathrm{C}-16$. The tetrahydrofuran ring $\mathrm{E}$ is cis-fused to the cyclopentane ring D. Finally the F-ring, which bisects the normal plane of the steroid skeleton, shows a C-25-endo envelope conformation with puckering parameters $Q(2)=0.369(3) \AA, \varphi(2)$ $=146.3(4)^{\circ}$, if the calculation follow this order: O(3), C-22, C-23, C-24, C-25, (See Table 5). The crystal structure of compound $\mathbf{1 1}$ is shown in Figure 5, with the ellipsoid drawn at the 50\% of probability. ${ }^{9 b}$

Table 5. Calculated puckering parameters for compound $\mathbf{1 1}$

\begin{tabular}{|c|c|c|c|c|}
\hline Ring & $\mathrm{Q} / \AA$ & $\theta /{ }^{\circ}$ & $\varphi /{ }^{\circ}$ & Order and direction of the calculation \\
\hline A & $0.555(2)$ & $178.0(2)$ & $242(5)$ & From $C(1)$ to $C(10)$, counterclockwise \\
\hline $\mathrm{B}$ & $0.578(2)$ & $3.2(2)$ & $226(4)$ & From $C(5)$ to $C(10)$, counterclockwise \\
\hline $\mathrm{C}$ & $0.569(2)$ & $9.6(2)$ & $255(1)$ & From $\mathrm{C}(8)$ to $\mathrm{C}(14)$, clockwise \\
\hline Ring & $\mathbf{Q}(2) / \AA$ & $\varphi / /^{\mathbf{o}}$ & & \\
\hline $\mathrm{D}$ & $0.445(2)$ & $202.3(3)$ & - & From $\mathrm{C}(13)$ to $\mathrm{C}(17)$, counterclockwise \\
\hline $\mathrm{E}$ & $0.350(2)$ & $186.2(4)$ & - & In this order; $\mathrm{O}(4), \mathrm{C}(22), \mathrm{C}(20), \mathrm{C}(17), \mathrm{C}(16)$ \\
\hline $\mathrm{F}$ & $0.369(3)$ & $146.3(4)$ & - & In this order: $\mathrm{O}(3), \mathrm{C}(22), \mathrm{C}(23), \mathrm{C}(24), \mathrm{C}(25)$ \\
\hline
\end{tabular}




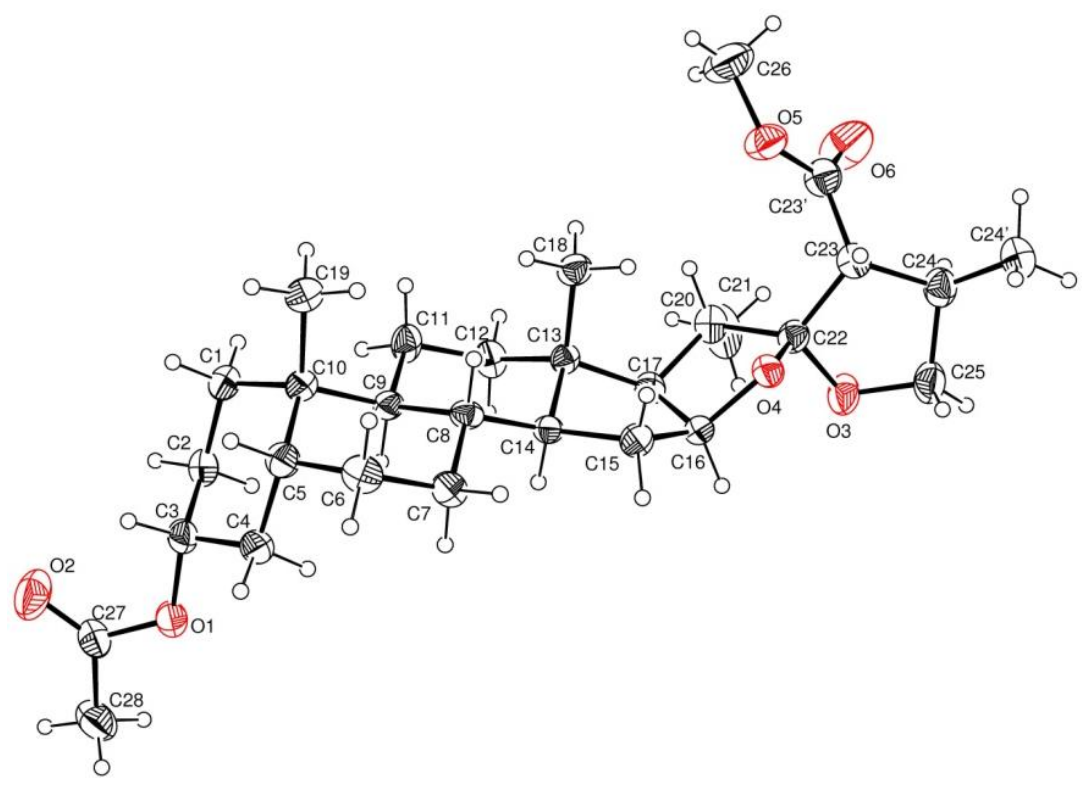

Figure 5. Crystal structure of compound 11.

The molecules in the unit cell of $\mathbf{1 1}$ show non-classic hydrogen bonds and they are linked via one hydrogen bond in the same cell $\mathrm{C}(24)-\mathrm{H}(24) . \mathrm{O}(6)(2.50 \mathrm{H} \ldots \mathrm{O}, 2.887(4) \mathrm{C} \mathrm{O})$ with other to the next cell, $\mathrm{C}(28)-\mathrm{H}(28 \mathrm{~B}) . \mathrm{O}(6)(2.54 \mathrm{H} \mathrm{O}, 3.439$ (3) $\mathrm{C} \mathrm{O}$ ). The packing of the crystal is assumed to be dictated by van der Waals interactions and intermolecular $\mathrm{CH}---\mathrm{O}$ hydrogen bonds. In figure 6 the main contacts of this molecule are shown.

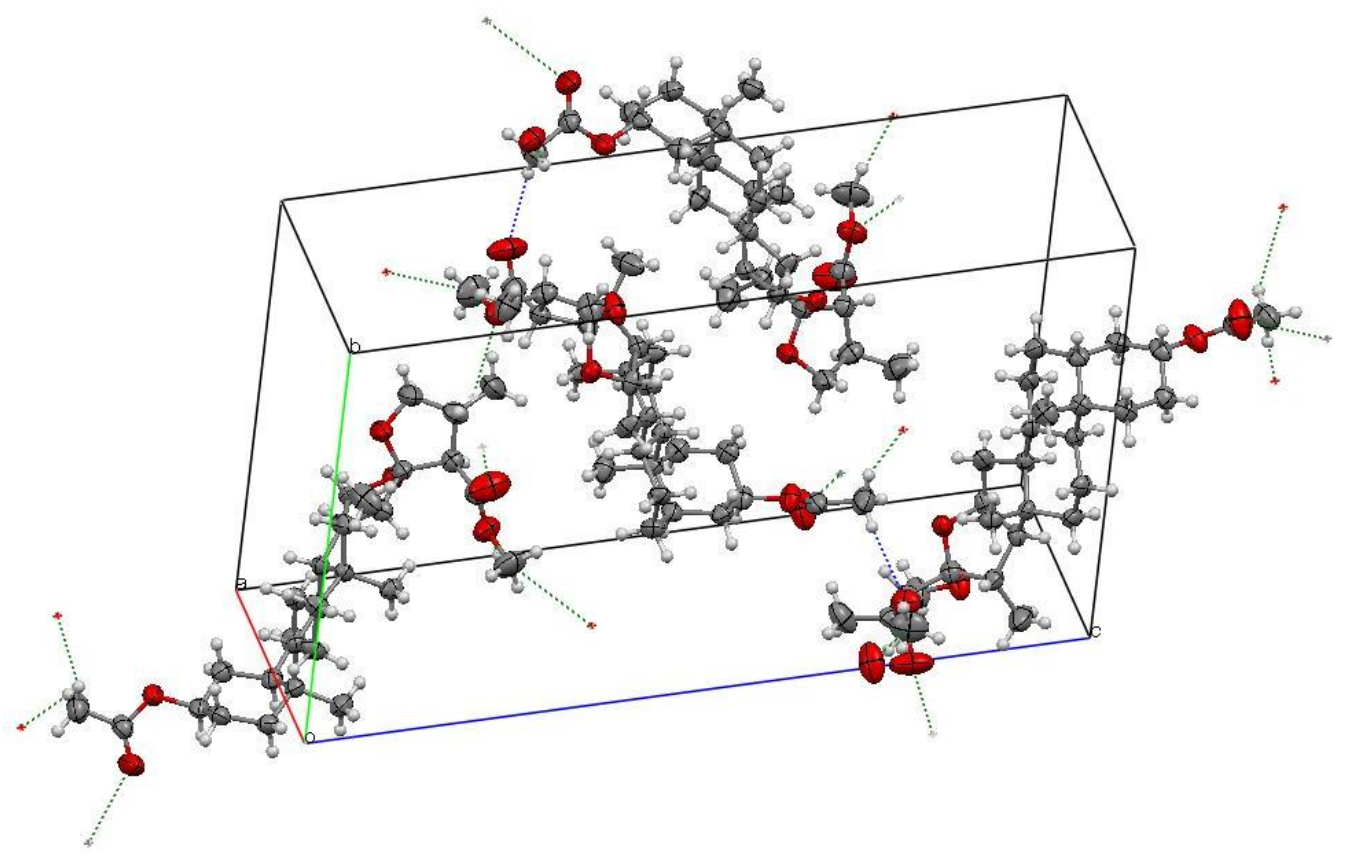

Figure 6. View of the unit cell and the main contacts of $\mathbf{1 1 .}$ 
As expected, in compound 12, the presence of the smaller equatorial hydroxyl substituent attached to $\mathrm{C}-3$ does not disturb the chair conformation of ring $\mathrm{A}$, which shows a puckering amplitude $(\mathrm{Q})=0.560(2) \AA, \theta=175.0(2)^{\circ}, \varphi=282(2)^{\circ}$, if the calculation starts from C-1 to C10 and proceeds in the counterclockwise direction. Ring $\mathrm{B}$ assumes a conformation very similar to a chair form with a puckering amplitude Puckering Amplitude $(\mathrm{Q})=0.573(2) \AA, \theta=4.5(2)^{\circ}$, $\varphi=227(2)^{\circ}$, if the calculation starts from C-5 to C-10 and proceeds in a counterclockwise direction. Ring $\mathrm{C}$ assumes a conformation close to a chair with a puckering amplitude $(\mathrm{Q})=$ $0.5550(19) \AA, \theta=10.7(2)^{\circ}, \varphi=247.5(11)^{\circ}$, if the calculation starts from C-8 to C-14 and proceeds in a clockwise direction. Ring D can be described as cyclopentane twisted on C-13-C14 with a conformation very similar to a half chair with puckering parameters of $\mathrm{Q}(2)=$ $0.4503(19) \AA, \varphi(2)=199.1(2)^{\circ}$, if the calculation starts from C-13 to C-17 and proceeds in a clockwise direction. Ring E display an envelope $\mathrm{O}(3)$-exo with absolute L configuration with puckering parameters $\mathrm{Q}(2)=0.3624(17) \AA, \varphi(2)=183.4(3)^{\circ}$, if the calculation follow this order; $\mathrm{O}(3), \mathrm{C}-22, \mathrm{C}-20, \mathrm{C}-17, \mathrm{C}-16$. The tetrahydrofuran ring $\mathrm{E}$ is cis-fused to the cyclopentane ring D. Finally the F-ring, which is perpendicular to the normal plane of the skeleton, shows an $\mathrm{C}$-22-endo envelope conformation with puckering parameters $\mathrm{Q}(2)=0.336(2) \AA, \varphi(2)=$ 212.5(4) ${ }^{\circ}$, if the calculation follow this order: O(2), C-22, C-23, C-24, C-25, (See Table 6). The crystal structure of compound $\mathbf{1 2}$ is shown in Figure 7, with the ellipsoid drawn at the $50 \%$ of probability. $^{9 \mathrm{~b}}$

Table 6. Calculated puckering parameters for compound $\mathbf{1 2}$

\begin{tabular}{ccccc}
\hline Ring & $\mathrm{Q} / \AA$ & $\theta /{ }^{\circ}$ & $\varphi^{\circ}$ & Order and direction of the calculation \\
\hline $\mathrm{A}$ & $0.560(2)$ & $175.0(2)$ & $282(2)$ & From $\mathrm{C}(1)$ to $\mathrm{C}(10)$, counterclockwise \\
$\mathrm{B}$ & $0.573(2)$ & $4.5(2)$ & $227(2)$ & From $\mathrm{C}(5)$ to $\mathrm{C}(10)$, counterclockwise \\
$\mathrm{C}$ & $0.555(2)$ & $10.7(2)$ & $248(1)$ & From $\mathrm{C}(8)$ to $\mathrm{C}(14)$, clockwise \\
Ring & $\mathrm{Q}(2) / \AA$ & $\rho^{\mathrm{o}}$ & & \\
$\mathrm{D}$ & $0.450(2)$ & $199.1(2)$ & - & From $\mathrm{C}(13)$ to $\mathrm{C}(17)$, counterclockwise \\
$\mathrm{E}$ & $0.362(2)$ & $183.4(3)$ & - & In this order: $\mathrm{O}(3), \mathrm{C}(22), \mathrm{C}(20), \mathrm{C}(17), \mathrm{C}(16)$ \\
$\mathrm{F}$ & $0.336(2)$ & $212.5(4)$ & - & In this order: $\mathrm{O}(2), \mathrm{C}(22), \mathrm{C}(23), \mathrm{C}(24), \mathrm{C}(25)$ \\
\hline
\end{tabular}




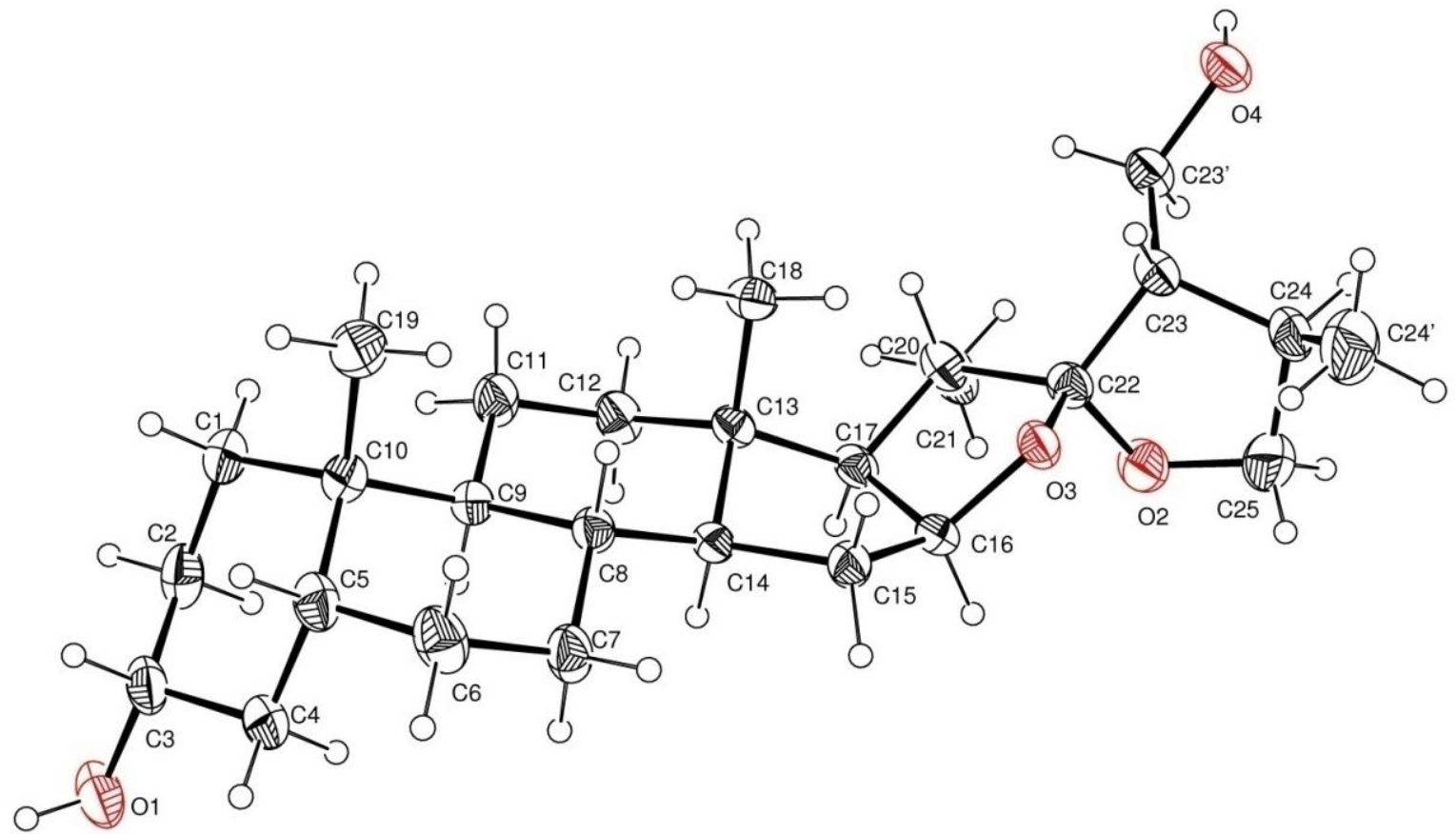

Figure 7. Crystal structure of compound 12.

The molecules in the unit cell of $\mathbf{1 2}$ are connected head to tail through these hydrogen bonds: $\mathrm{O}(1)-\mathrm{H}(10)$. O(4) (1.93(4) H O, 2.777(2) O O) and $\mathrm{O}(4)-\mathrm{H}(40)$. O(1) (1.82(4) H O, 2.704(2) O $\mathrm{O})$ in consecutive unit cells, the main contacts for this molecule are presented in Figure 8.

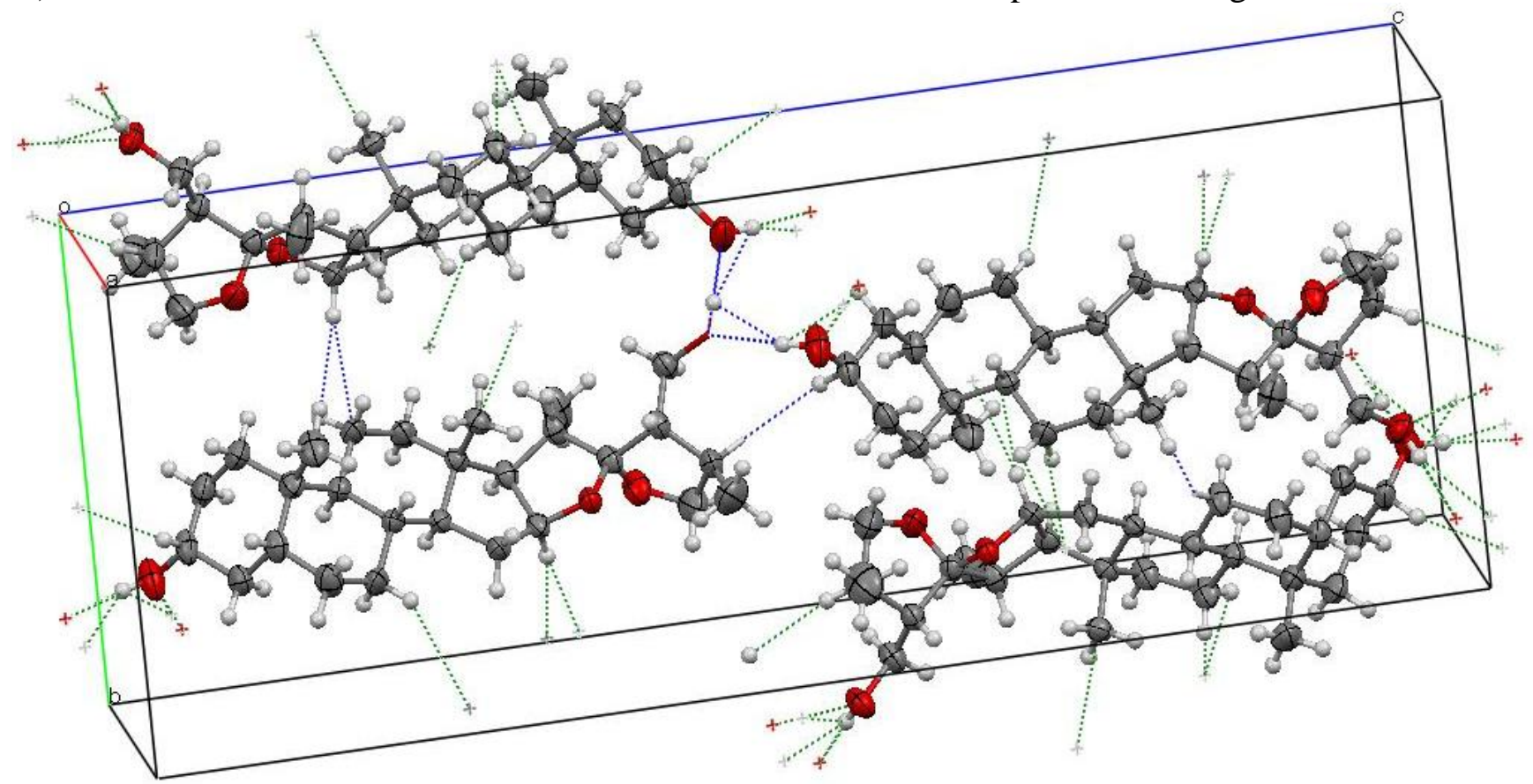

Figure 8. View of the main contacts of $\mathbf{1 2 .}$ 
In order to establish quantitative differences between the studied compounds $\mathbf{1 1}$ and 12, a least-squares overlay analysis of the structures is performed. Table 7 shows the results of leastsquares overlay analysis obtained with the Mercury program. ${ }^{9 \mathrm{c}}$ From the obtained data it is clear that, as expected, the modifications introduced in the side chain do not produce significant conformational changes in the steroid framework, at least qualitatively.

Table 7. Least squares overlay analysis of the rings

\begin{tabular}{cc}
\hline RINGS & RMS of 12 vs 11 \\
\hline A & 0.0186 \\
B & 0.0088 \\
C & 0.0108 \\
D & 0.0150 \\
E & 0.0115 \\
F & 0.1770 \\
\hline
\end{tabular}

Interestingly, when F-rings of $\mathbf{1 1}$ and $\mathbf{1 2}$ are compared, it becomes evident that the envelope configuration shifts from $\mathrm{C}(25)$ in $\mathbf{1 1}$ to $\mathrm{C}(22)$ in $\mathbf{1 2}$, making the overlay between these two rings very bad and indicating evident differences in the conformations adopted by the side chains of $\mathbf{1 1}$ and 12. Table 8 shows the puckering descriptors as defined by Cremer and Pople ${ }^{9 a}$ and calculated using the PLATON program. ${ }^{9 \mathrm{~d}-\mathrm{e}}$ The minor differences observed amongst rings A to $\mathrm{D}$ across all compounds may be attributed to the different intermolecular interactions that are, of course, influenced by the changes introduced in the side chain.

Table 8. Puckering descriptors obtained using the PLATON program

\begin{tabular}{lcc}
\hline & $\mathbf{1 1}$ & $\mathbf{1 2}$ \\
\hline Ring A & C-form & Very Similar to a C-form \\
Ring B & Very Similar to a C-form & Very Similar to a C-form \\
Ring C & Close to a C-form & Close to a C-form \\
Ring D & Twisted on C(13)-C(14) & Twisted on C(13)-C(14) \\
Ring E & Envelope O(4)-exo & Envelope O(3)-exo \\
Ring F & Envelope C(25)-endo & Envelope C(22)-endo \\
\hline
\end{tabular}

While the quite similar coupling constants of F-ring protons of compounds $\mathbf{1 1}$ and $\mathbf{1 2}$ (see Table 3) indicate that, in solution, both side chains adopt very similar conformations, the important -and somehow unexpected- conformational changes observed between both side chains in the solid state, should be associated with the different crystal packing of compounds $\mathbf{1 1}$ and 12, (see Figures 6 and 8). 


\section{Experimental Section}

General. Reactions were monitored by TLC on Alugram ${ }^{8}$ SIL G/UV254 plates from MachereyNagel. Chromatographic plates were sprayed with a $1 \%$ solution of vanillin in $50 \% \mathrm{HClO}_{4}$ and heated until color developed. Melting points were measured on a Melt-Temp II equipment. Mass spectra were registered in a Thermo-Electron spectrometer model DFS (Double Focus Sector). NMR spectra were recorded in $\mathrm{CDCl}_{3}$ solution in a Varian Inova 400 spectrometer using the solvent signal $7.26 \mathrm{ppm}$ for ${ }^{1} \mathrm{H}$ and $77.00 \mathrm{ppm}$ for ${ }^{13} \mathrm{C}$ as references. NMR signals assignment was made using a combination of $2 \mathrm{D}$ homonuclear and heteronuclear correlation techniques, which included ${ }^{1} \mathrm{H}-{ }^{1} \mathrm{H}$ COSY, ${ }^{1} \mathrm{H}-{ }^{1} \mathrm{H}$ Nuclear Overhauser effect (NOESY), Heteronuclear Single Quantum Correlation (HSQC) and Heteronuclear Multiple Bond Correlation (HMBC). All 2D NMR spectra were recorded using the standard pulse sequences and parameters recommended by the manufacturer and processed using Mestrenova (http://mestrelab.com). Copies of the spectra can be found in the supplementary information file.

$(22 S, 23 R, 24 R)-16 \beta, 22: 22,25$-diepoxy-23-carboxymethyl-24-methyl-26,27-dinor-5 $\beta$-cholestan-3 $\alpha$-ol acetate (11). Acetic anhydride $0.8 \mathrm{~mL}$ was added to a solution of $\mathbf{1 0}^{1 \mathrm{ff}}$ in pyridine ( 8 $\mathrm{mL}$ ), the mixture was stirred overnight, poured into a mixture of ice and $50 \mathrm{~mL}$ of $10 \% \mathrm{HCl}$. The mixture was extracted with ethyl acetate $(2 \times 40 \mathrm{~mL})$ and the organic layer was washed with $10 \%$ $\mathrm{HCl}$ solution $(2 \times 25 \mathrm{~mL}), 5 \% \mathrm{CuSO}_{4}$ solution $(3 \times 25 \mathrm{~mL})$, water $(2 \times 30 \mathrm{~mL})$, dried $\left(\right.$ anh. $\left.\mathrm{Na}_{2} \mathrm{SO}_{4}\right)$ and evaporated to afford the acetylated product 11 (1.06 g, $2.11 \mathrm{mmol}, 75 \%)$. m.p. $172-174{ }^{\circ} \mathrm{C}$ from acetone/hexane. See tables 3 and 4 for ${ }^{1} \mathrm{H}$ and ${ }^{13} \mathrm{C}$ NMR signals. MS (EI, $70 \mathrm{eV}$ ): $503 \mathrm{MH}^{+}$, 471, 469. Elem. Anal Calc. for $\mathrm{C}_{27} \mathrm{H}_{44} \mathrm{O}_{4}: \mathrm{C}, 71.68, \mathrm{H}, 9.22 \%$. Found: C, 71.61, H 9.31\%. (22S,23S,24R)-16 $\beta, 22: 22,25$-diepoxy-23-hydroxymethyl-24-methyl-26,27-dinor-5 $\beta$-cholestan-3 $\alpha$-ol (12). A solution of the rearranged product $\mathbf{1 0}^{\text {1f }}(643 \mathrm{mg}, 1.39 \mathrm{mmol})$ in THF (15 ml) was slowly added to a refluxing suspension of $\mathrm{LiAlH}_{4}(643 \mathrm{mg}, 1.39 \mathrm{mmol})$ in THF $(25 \mathrm{~mL})$ under nitrogen and the mixture was refluxed for 2 hours. Ethyl acetate $(30 \mathrm{~mL})$ was carefully added to destroy the excess of $\mathrm{LiAlH}_{4}$ (caution !!) followed by water $(30 \mathrm{~mL})$ and the mixture was extracted with ethyl acetate $(2 \times 50 \mathrm{~mL})$. The organic layer was washed with water $(5 \times 30 \mathrm{~mL})$ dried (anh. $\mathrm{Na}_{2} \mathrm{SO}_{4}$ ) and evaporated to afford the reduced compound 12, $(512.5 \mathrm{mg}, 1.18 \mathrm{mmol}$, 85\%). m.p. $177-178{ }^{\circ} \mathrm{C}$ from ethyl acetate/hexane. See tables 3 and 4 for ${ }^{1} \mathrm{H}$ and ${ }^{13} \mathrm{C}$ NMR signals. MS (EI, 70e V): $433 \mathrm{MH}^{+}, 415,397,385,367,285,255,155,137,125$. HRMS-EI $433.3321\left(\mathrm{MH}^{+} \mathrm{C}_{27} \mathrm{H}_{45} \mathrm{O}_{4}\right.$ requires 433.3318)

Suitable crystals for X-Ray diffraction studies were obtained from the analytical samples as follows: crystals of $\mathbf{1 1}$ from a 10/1 mixture of hexane/ethyl acetate by slow evaporation; and crystals of $\mathbf{1 2}$ from an acetone solution left at $4^{\circ} \mathrm{C}$ for several days. Compounds 11 and $\mathbf{1 2}$ crystallized as orthorhombic systems with space group P $22_{1} 2_{1} 2_{1}$. X-Ray diffraction measurements were performed at 293 (2) K on an Oxford Diffraction Atlas (Gemini) diffractometer with Mo $\mathrm{K}_{\alpha}$ radiation $\lambda=0.71073 \AA$. Data collection routine and data reduction were carried out with CrysAlisPro, Oxford Diffraction Ltd. Oxford Diffraction. ${ }^{10 a}$ The structures of both molecules 
were solved using SIR2004 ${ }^{10 \mathrm{~b}}$ and refined using SHELXL-97. ${ }^{10 \mathrm{c}}$ All non-hydrogen atoms were refined anisotropically and the hydrogen atoms were found in the difference Fourier maps, placed at geometrically calculated positions and refined using the riding model. The obtained bond lengths and angles of each compound are normal and are available from the electronic supporting information (CIF file) for the structure. Crystallographic data have been deposited with the Cambridge Crystallographic Data Center as supplementary material numbers CCDC 773328 (11) and CCDC 773330 (12). Copies of the data can be obtained free of charge on application to CCDC, 12 Union Road, Cambridge CB2 1EZ, UK. E-mail: deposit@ccdc.cam.ac.uk.

\section{Acknowledgements}

The authors thank to the Dirección General de Asuntos del Personal Académico (DGAPAUNAM) for financial support via project IN221911-3 and to CONACyT for scholarship granted to MMA. Thanks are due to Georgina Duarte Lisci (USAI-UNAM) for registering mass spectra.

\section{References}

1. (a) Fieser, L.; Feiser, M. Steroids. New York: Reinhold Publishing Corporation. 1959. (b) Callow, R. K; James, V. H. T.; Kennard, O.; Page, J. E.; Paton, P. N.; Riva di Sanseverino, L. J. Chem. Soc. C 1966, 288. (c) Iglesias-Arteaga, M. A.; Velázquez-Huerta, G. A.; MéndezStivalet, J. M.; Galano, A; Álvarez-Idaboy, J. R. Arkivoc 2005, vi, 109. (d) Iglesias-Arteaga, M. A.; Alvarado-Nuño, A. A. Tetrahedron Lett. 2006, 47, 5351. (e) Iglesias-Arteaga, M. A.; Jastrzêbska, I; Morzycki, J. W. Polish J. Chem. 2006, 80, 667. (f) Iglesias-Arteaga, M. A.; Velázquez-Huerta, G. A. Tetrahedron Lett. 2005, 46, 6897. (g) Hernández, R.; MarreroTellado, J. J.; Prout, K.; Suárez, E. J. Chem. Soc., Chem. Commun. 1992, 275. (h) Betancor, C.; Dorta, R. L.; Freire, R.; Martín, A.; Prangé, T.; Suárez, E. J. Org. Chem. 1998, 63, 6355. (i) LaCour, T. G.; Tong, Z.; Fuchs, P. L. Org. Lett. 1999, 1, 1815. (j) Cyrański, M. K.; Frelek, J.; Jastrzêbska, I.; Morzycki, J. W. Steroids 2004, 69, 395. (k) Anulewicz-Ostrowska, R.; Jastrzêbska, I.; Morzycki, J. W.; Wojcik, J. J. Org. Chem. 2002, 67, 6916. (1) Jastrzêbska, I.; Morzycki, J. W. Polish J. Chem. 2005, 79, 1245. (m) López, Y.; Ruíz-Pérez, K. M.; Yépez, R.; Santillán, R.; Flores-Álamo, M.; Iglesias-Arteaga, M. A. Steroids 2008, 73, 657.

2. (a) Corbiere, C.; Liagre, B.; Terro, F.; Beneytout, J. L. Cell Research 2004, 14, 188. (b) Corbiere, C.; Liagre, B.; Bianchi, A.; Bordji, K.; Dauca, M.; Netter, P.; Beneytout, J. L. Int. J. Oncol. 2003, 22, 899. (c) Raju, J.; Patlolla, J. M. R.; Swamy, M. V.; Rao, C. V. Cancer Epidemiol. Biomarkers Prev. 2004, 13, 1392. (d) Fattorusso, E.; Lanzotti, V.; Magno, S.; Taglialatela-Scafati, O. J. Agric. Food Chem. 1998, 46, 4904. (e) Carotenuto, A.; Fattorusso, E.; Lanzotti, V.; Magno, S.; De Feo, V.; Carnuccio, R.; D’Acquisto, F. J. Nat. Prod. 1997, 
60, 1003. (f) Carotenuto, A.; Fattorusso, E.; Lanzotti, V.; Magno, S.; Carnuccio, R.; D’Acquisto, F. Tetrahedron 1997, 53, 3401.

3. Lee, E.; Liu, Y. T.; Solomon Philippa, H.; Nakanishi, K. J. Am. Chem. Soc. 1976, 98, 1634.

4. (a) Iglesias Arteaga, M. A.; Pérez-Gil, R.; Pérez-Martinez, C. S.; Coll-Manchado, F. J. Chem. Soc., Perkin Trans. 2001, 1, 261. (b) Iglesias-Arteaga, M. A.; Pérez-Martínez, C. S.; Coll-Manchado F. Steroids 2002, 67, 159. (c) Romero-Ávila, M.; de Dios-Bravo, G.; Méndez-Stivalet, J. M.; Rodríguez-Sotres R.; Iglesias-Arteaga M. A. Steroids 2007, 72, 955.

5. (a) Jiang, B.; Shi, H-P; Tian, W-S; Zhou, W-S. Tetrahedron 2008, 64, 469. (b) Xu, Q-H; Peng, X-W; Tian, W-S. Tetrahedron Lett. 2003, 44, 9375. (c) Gryszkiewicz-Wojtkielewicz, A.; Jastrzêbska, I.; Morzycki, J.W.; Romanowska, D.B. Curr. Org. Chem. 2003, 7, 1257. (d) Ravindar, K.; Reddy, M.S.; Lindqvist, L.; Pelletier, J.; Deslongchamps, P. J. Org. Chem. 2011, 76, 1269.

6. (a) Rao, Ch. B.; Ramana, K. V.; Rao, D. V.; Fahy, E.; Faulkner, D. J. J. Nat. Prod. 1988, 51, 954. (b) González, N.; Barral, M. A.; Rodriguez, J.; Jiménez, C. Tetrahedron 2001, 57, 3487. (c) Sheu, J-H; Chao, C-H; Wang, G-H; Hung, K-C; Duh, C-Y; Chiang, M-Y; Wu, Y-C; Wud, C-C. Tetrahedron Lett. 2004, 45, 6413. (d) Chao, C-H; Huang, L-F; Yang, Y-L; Su, JH; Wang, G-H; Chiang, M-Y; Wu, Y-C; Dai, C-F; Sheu, J-H. J. Nat. Prod. 2005, 68, 880.

7. (a) Kirk, D. N.; Toms, H. C.; Douglas, C.; White, K. A.; Smith, K. E.; Latif, S.; Hubbard, R. W. P. J. Chem. Soc., Perkin Trans. 2 1990, 9, 1567. (b) Agrawal, P. K.; Bunsawansong, P.; Morris, G. A. Magn. Reson. Chem. 1997, 35, 441.

8. (a) Blunt, J. W.; Stothers, J. B. Org. Magn. Resonance 1977, 9, 439. (b) Agrawal, P. K.; Jain, D. C.; Gupta, R. K.; Thakur, R. S. Phytochemistry 1985, 24, 2479. (c) Iglesias-Arteaga, M. A.; Pérez-Martínez, C. S.; Pérez-Gil, R.; Coll-Manchado, F. J. Chem. Res. (S) 1999, 48. (d) Viñas-Bravo, O.; Hernández-Linares, G.; Mata-Esma, M. Y.; Martínez-Pascual, R.; MontielSmith, S.; Meza-Reyes, S.; Bernès, S.; Sandoval-Ramírez, J.; Iglesias-Arteaga, M. A. ARKIVOC 2003, xi, 163. (e) Macias-Alonso, M.; Esturau-Escofet, N.; Flores-Alamo, M.; IglesiasArteaga, M. A.; Moreno-Esparza, R. J. Chem Crystallogr. 2011, DOI 10.1007/s10870-0110126-3.

9. (a) Cremer, D.; Pople, J. A. J. Am. Chem. Soc. 1975, 97, 1354-1358. (b) Farrugia, L. J. Appl. Cryst. 1997, 30, 565. (c) Macrae, C. F.; Bruno, I. J.; Chisholm, J. A.; Edgington, P. R.; McCabe, P.; Pidcock, E.; Rodriguez-Monge, L.; Taylor, R.; Van de Streek, J.; Wood, P. A. J. Appl. Cryst. 2008, 41, 466. (d) Spek, A. L. Acta Cryst., Sect. A. 1990, 46, C34. (e) Spek, A. L. 1998, PLATON, A Multipurpose Crystallographic Tool, Utrecht University, Utrecht, The Netherlands.

10. (a) CrysAlis CCD and CrysAlis Red, V. 171. 33. 31. Abingdon, England: Oxford Diffraction 2009. (b) Giacovazzo, C.; Burla, M. C.; Caliandro, R.; Camalli, M.; Carrozzini, B.; Cascarano, G.L.; et al. SIR-2004 (v 1.0) a program for automatic solution and refinement of crystal structures. 2004. (c) Sheldrick G. M. Acta. Cryst. 2008, A64, 112. 